\title{
BY CHOICE OR BY CIRCUMSTANCE?: STEREOTYPES OF AND FEELINGS ABOUT SINGLE PEOPLE
}

\author{
Gal SLONIM ${ }^{1}$, Nurit GUR-YAISH ${ }^{1}$, Ruth KATZ ${ }^{2}$ \\ ${ }^{1}$ Department of Psychology, The University of Haifa \\ Haifa, Israel \\ E-mail: slonim.gal@gmail.com \\ ${ }^{2}$ Department of Human Services, Center for Research and Study of Family \\ The University of Haifa \\ Haifa, Israel
}

\begin{abstract}
The study examines stereotypes of and emotional reactions to singles by choice and singles not by choice. Participants $(N=480)$ read a scenario describing persons, who were either single by choice or single not by choice and rated their thoughts and feelings about these persons. Singles by choice are perceived as more lonely and miserable, and as less warm and sociable, than singles not by choice. However, they are perceived as more successful and potent. Anger and sympathy mediate the relations between choosing singlehood and stereotyping levels. These findings extend the way in which the Attribution Theory explains activation of stereotypes.
\end{abstract}

Key words: singles, singlism, stereotypes, emotions, attribution theory

In recent years, researchers have increasingly used the term "socially single", which suggests that what matters most in everyday life is whether a person is in a significant romantic relationship or not, regardless of his or her legal marital status (DePaulo \& Morris, 2006). The goal of our study was to examine whether "socially single" people are perceived differently than coupled people, and to determine whether a choice to remain single affected the intensity of stereotypes. In addition, we examined whether the emo-

\section{Funding}

This research received no specific grant from any funding agency in the public, commercial or not-for-profit sectors.

Conflict of Interest Statement

The authors declare that there is no conflict of interest. tions experienced regarding people who are single by choice and people who are single not by choice mediate the activation of stereotypes.

\section{The Increasing Phenomenon of Singlehood}

The rate of single people in the Western world is constantly increasing. In the United States, $50.2 \%$ of the adult population -124.6 million people - were single in August 2014. For comparison, the rate of adult single people in the US was $37.4 \%$ in 1976 (U.S. Bureau of Labor Statistics, 2014). Israel has also witnessed such a trend: since 1970, the rate of single men has doubled, and the rate of single women has tripled (Israel Central Bureau of Statistics, 2012).

DOI: $10.21909 /$ sp.2015.01.672 


\section{Stereotypes of Single People}

While the rate of single people is increasing, negative stereotyping of and discrimination against single people (i.e., "singlism"; DePaulo \& Morris, 2006) has been well-documented in the United States (DePaulo \& Morris, 2005a, 2005b, 2006; Morris, DePaulo, Hertel, \& Taylor, 2008) and in Germany (Greitemeyer, 2009; Hertel, Schütz, DePaulo, Morris, \& Stucke, 2007).

When American students were asked to list traits describing married or single people, they described married people as more mature, stable, honest, happy, kind, and loving than single people. In contrast, they described single people as more immature, insecure, self-centered, sad, lonely, and ugly than married people (Morris, DePaulo, Hertel, \& Taylor, 2008). Greitemeyer (2009) reported that single targets were perceived as less extraverted, conscientious, agreeable, sociable, physically attractive and satisfied with their lives than coupled targets. In his study, single targets were also perceived as lonelier and as having a lower self-esteem than partnered targets. In another study, German participants rated single people higher than married people on measures of loneliness and misery, and lower on measures of warmth and concern for others (Hertel et al., 2007).

\section{What Moderates Stereotypes of Singles?}

Age and gender were tested in previous research as potential moderators of stereotypes of singles. Young, 25-year-old singles are perceived less negatively than older, 40year-old singles (Hertel et al., 2007; Morris, DePaulo, Hertel, \& Taylor, 2008). One expla- nation for this finding is that, according to the Developmental Life Tasks Model (Morris, DePaulo, Hertel \& Taylor, 2008), getting married (or at least taking steps toward marriage by becoming coupled) is considered an important developmental milestone, and that mission should be accomplished by a certain age. Younger singles might be perceived as able to eventually find a partner, whereas the probability of finding a partner decreases with age.

Another moderator tested in previous studies is gender. Women are perceived as having a higher desire for marriage and children than men (Erchull, Liss, Axelson, Staebell, \& Askari, 2010), and therefore one might predict that the stereotyping of single women would be more pronounced than that of single men. However, gender was not found to affect stereotypes of singles - single women are judged just as negatively as single men (Conley \& Collins, 2002; Greitemeyer, 2009; Hertel et al., 2007). The current study examines the extent to which the single person chooses to remain single as another possible moderator of singlism.

\section{Singles Who Choose to Remain Single versus Those Who Do Not}

In their typology of single people, both Shostak (1987) and Barkas (1980) suggested that whether the single person chooses or not to remain single is an important classification. However, this classification was not considered in previous research. Why would each type of singles be stereotyped to a different extent? According to the System Justification Theory (Jost, Banaji, \& Nosek, 2004; Jost \& Hunyady, 2002; Jost \& Hunyady, 2005), people are motivated to justify and rationalize the existing social, economic and 
political structures, by perceiving the status quo as fair and legitimate. These beliefs help reduce uncertainty and avoid threatening situations. Based upon System Justification Theory's assumptions, a prediction can be made that singles who choose to remain single, and by that reject the status quo, would evoke defensive reactions such as negative stereotypes. In a series of recent studies on the relations between system justification and the ideology of committed relationship (Day, Kay, Holmes, \& Napier, 2011), it was found that when the system justification motive is heightened, people tend to increase their identification with their personal romantic relationship, probably as a means to defend the way things are or the way things should be. We assume that singles who chose to remain single would be more negatively stereotyped, as they do not seem to share the cultural belief in the importance of coupling and marriage and are perceived as threatening the continuity of the status quo.

\section{The Mediating Role of Emotions on Levels of Singlism}

According to Weiner's Attribution Theory (Weiner, 1986, 1993), when people judge information about a negative, irregular or unacceptable phenomenon, they try to ascribe a reason to the situation. The reason they provide affects their emotions, depending on the attribution of causality that they activate. If the negative situation is perceived as one that can be controlled, in other words, if it stems from a choice that was made, it elicits feelings of anger, whereas when the situation is perceived as uncontrolled, as something that was not chosen, sympathy is the predominant experienced emotion. This theo- retical prediction has empirical support. For instance, the failure of a student that was perceived as stemming from his low capacities was found to elicit feelings of mercy and sympathy among his teachers. However, failure that was perceived as stemming from a student's lack of effort made the teachers angry, since in this case, the student's control over his situation was greater (Weiner, Graham, Stern, \& Lawson, 1982). A more recent study on emotional responses to patients with AIDS found that perceptions of responsibility for the situation resulted in different emotional outcomes. When a sick person was perceived as more responsible for contracting the disease (having unsafe sexual relations) as compared with less responsible for his/her situation (contracting the disease via a needle prick by an unwary nurse), the participants felt more anger, restlessness, and nervousness and less empathy, sadness, and concern for that person (Badahdah \& Alkhder, 2006). Based on these studies derived from the Attribution Theory, and on Weiner's argument that reactions to stigmatized people are psychologically comparable with reactions to people who fail (Weiner, 1993), one may assume, that this pattern of emotional responses would also occur with respect to people who remain single by choice versus people who remain single not by choice. Thus, negative emotions such as anger would be experienced toward singles who chose to remain single, whereas more positive, warm emotions of sympathy would be experienced toward people who did not choose to remain single.

To conclude, based upon previous research under the frameworks of the Attribution Theory and System Justification Theory, we assume that singles who do not seem to be interested in remaining single 
are perceived as being in an unpleasant and undesired situation. This situation might change in the future, and these single people might find a partner. Thus, these singles would elicit feelings of sympathy, which in turn would reduce the levels of stereotyping. In contrast, single individuals who choose to remain single and do not seek a romantic relationship would be perceived as undermining the value of establishing a family. This will lead to their being labeled as abnormal, different, and threatening and, thus, would elicit feelings of anger, which in turn elevate the negative stereotypes of such singles.

Our study advances the knowledge about singlism in three important respects: first, by testing whether negative stereotypes of single people also exist in the Israeli culture; second, by exploring the effect that choosing or not choosing to remain single has on stereotypes of singles; and third, by examining the mediating role that emotions play in the relations between choosing to remain single and stereotypes of singles.

Specifically, we hypothesized the following:

1. People who are not coupled would be perceived more negatively compared to people who are in a romantic relationship.

2. People who choose to remain single would be more negatively stereotyped in comparison to people who remain single not by choice.

3. Emotions with respect to the single person would mediate the relationship between the choice to remain single and levels of stereotyping, so that sympathy would decrease the stereotypes of individuals who remain single not by choice, and anger would increase the stereotypes of individuals who remain single by choice.

\section{Method}

\section{Participants}

Four hundred eighty Israeli respondents, 193 men and 287 women, participated in the study; their ages ranged between 18 and 65 $(M=28.3, S D=8.7)$. Forty-four percent of the participants were married or living with a partner, and 53\% were single. The remaining participants (about 3\%) were either divorced or separated. The participants' years of education ranged from 9 to $22(M=14.0, S D=$ 2.9).

\section{Measures}

A scenario describing a target figure. Each participant was asked to read a short paragraph describing a target figure. The study included 12 different scenario versions: 8 of them described single figures, and the other 4 described figures in a romantic relationship. Information provided about the single target figures included (a) his or her age (25 in half the versions, 40 in the rest), (b) sex (male or female), and (c) whether they chose to remain single or did not choose that. Information provided about the partnered target figures included (a) his or her age (25 in half the versions, 40 in the rest) and (b) sex (male or female). In addition, the paragraph included information about the figure's occupation, leisure activities and favorite colors, in order to mask the goal of the study (we used the same filler information for all 12 scenarios). An example of a scenario: "Yael, aged 25, lives in Ramat-Gan. She works in a bank. In her spare time she likes watching TV. Her favorite colors are red and blue. Yael has never been involved in a signifi- 
cant romantic relationship. She has decided that she prefers to remain single".

Stereotypes questionnaire. Stereotype levels were measured using Hertel et al.'s (2007) questionnaire. Participants were asked to rate on a 9-point scale ranging from 1 (not at all) to 9 (very much) how accurately each of the 33 traits (e.g., sociable, dependent, boring) described the target figure. The questionnaire was translated into Hebrew by the first author; afterwards, it was back translated into English by the second author; both authors

Table 1 Exploratory factor analysis for the stereotyping questionnaire

\begin{tabular}{|c|c|c|c|}
\hline \multirow[b]{2}{*}{ Trait } & \multicolumn{3}{|c|}{ Factor } \\
\hline & $\begin{array}{l}\text { Warmth and } \\
\text { sociability }\end{array}$ & $\begin{array}{c}\text { Success and } \\
\text { potency }\end{array}$ & $\begin{array}{l}\text { Loneliness } \\
\text { and misery }\end{array}$ \\
\hline Caring & .763 & & \\
\hline Outgoing & .749 & & \\
\hline Fond of children & .745 & & \\
\hline Warm-hearted & .707 & & \\
\hline Sympathetic & .682 & & \\
\hline Tolerant & .653 & & \\
\hline Emotionally open & .617 & & \\
\hline Many friends & .600 & & \\
\hline Close friends & .573 & & \\
\hline Willing to compromise & .569 & & \\
\hline Flexible & .568 & & \\
\hline In love with life & .555 & .477 & \\
\hline Content & .488 & .430 & \\
\hline Dependent & .425 & & \\
\hline Self-assured & & .663 & \\
\hline Independent & & .642 & \\
\hline Sophisticated & & .594 & \\
\hline Adventurous & & .589 & \\
\hline Attractive & & .580 & \\
\hline Career-oriented & & .563 & \\
\hline Interesting & & .539 & \\
\hline Stubborn & & .522 & .470 \\
\hline Intelligent & & .511 & \\
\hline Pleasure-loving & .473 & .487 & \\
\hline Happy & .431 & .480 & \\
\hline Fearful & & & .761 \\
\hline Depressive & & & .750 \\
\hline Lonely & & & .707 \\
\hline Shy & & & .605 \\
\hline Egoistic & & & .481 \\
\hline Boring & & & .469 \\
\hline Envious & & & .429 \\
\hline
\end{tabular}


are native English and Hebrew speakers. Discrepancies found in the back translation were discussed until agreement was reached. Following Hertel et al.'s procedure, we conducted an exploratory factor analysis with Varimax rotation on the data. This yielded three factors that together explained $45.2 \%$ of the variance (see Table 1). Factor 1 explained $20.9 \%$ of the variance, and was labeled Warmth and Sociability; Factor 2 explained $14.7 \%$ of the variance, and was labeled Success and Potency; and Factor 3 explained $9.5 \%$ of the variance, and was labeled Loneliness and Misery.

The trait "responsible" did not achieve a strong enough loading on any of the factors and therefore was not included in the subsequent analyses. Five traits were loaded on two different factors. Cronbach's alpha coefficients for each factor were $\alpha_{1}=.91, \alpha_{2}=$ .86 , and $\alpha_{3}=.74$, respectively.

Emotional reaction. Participants answered two questions about their positive and negative feelings: "How sympathetic do you feel about the target figure?" and "How angry do you feel about the target figure?" respectively, following Badahdah and Alkhder (2006). Participants were asked to rate the intensity of their feelings on a 7point scale ranging from 1 (not at all) to 7 (verymuch).

Demographic questionnaire. A short demographic questionnaire included questions about participants' gender, marital status, age, and years of education.

\section{Procedure}

The study was approved by the ethics committee at the University of Haifa Department of Psychology. Information describing the study was posted on Internet Web sites and forums targeting various age groups and interests, including forums titled "Twenty Plus," "Thirty Plus," "Forty Plus," "Sports," and "Television," on most popular Israeli Internet portals. In addition, ads were published on university and college Web sites and on Internet bulletin boards in order to reach the broadest audience possible.

The study questionnaire was uploaded to Google Spreadsheets Web site, which is an online platform for the collection of scientific data using polls and questionnaires. Each advertisement included a link to the study questionnaire. Each respondent was randomly assigned to one of the 12 scenario versions (40 responses were collected for each scenario). Respondents had a chance to win a prize (about $\$ 25$ in gift certificates for two winning participants).

\section{Results}

Preliminary analyses were conducted to examine differences between the 12 study groups for the demographic variables gender, marital status, age, and years of education. The analyses indicated that there were no significant differences between the study groups in terms of these sociodemographic attributes.

\section{Stereotypes of Single People in Compari- son with People in a Romantic Relationship, by Age and Gender}

In order to test Hypothesis 1, we conducted a multivariate analysis of variance (MANOVA) implementing Hotelling's Trace criterion. The three independent variables were the target figure's status (single/ coupled), age, and gender, and the three dependent variables were the three factors ob- 
tained from the factor analysis: warmth and sociability, loneliness and misery, and success and potency (see Table 2).

The analysis revealed differences between single people and people who are in a romantic relationship in the weighted dependent variable $(F(3,470)=59.78, p<.001)$. In accordance with the hypothesis, univariate analyses revealed a significant effect for the status of the target figure on perceived level of warmth and sociability $(F(1,472)=35.65$, $p<.001)$. The perceived warmth and sociability of single people $(M=4.20, S D=1.17)$ was lower than that of people in a romantic relationship $(M=4.89, S D=1.24)$. In addition, a significant effect was found for the status of the target figure on perceived loneliness and misery $(F(1,472)=115.85, p<.01)$. The perceived loneliness and misery of single people $(M=5.20, S D=1.09)$ was higher than that of people in a romantic relationship $(M$
$=4.01, S D=1.26)$. No significant effect was found for the status of the target figure on perceived level of success and potency $(F(1$, $472)=0.34$, n.s.); see Table 2 . No other significant main effects or interactions were found.

\section{Stereotypes of Single People who Chose to Remain Single versus Single People who Did Not Choose to Remain Single}

A MANOVA was performed using Hotelling's Trace criterion. The independent variable was the choice to remain single (chose/did not choose), and the three dependent variables were warmth and sociability, loneliness and misery, and success and potency (see Table 3 ).

The analysis revealed differences between singles who chose to remain single and singles who did not choose to remain single

Table 2 Main effects of relationship status

\begin{tabular}{lcccccc}
\hline & \multicolumn{8}{c}{ Factor } \\
\cline { 2 - 7 } Relationship status of target & $M$ & $S D$ & $M$ & $S D$ & $M$ & $S D$ \\
\hline Single & 4.20 & 1.17 & 5.20 & 1.09 & 4.68 & 1.15 \\
In romantic relationship & 4.89 & 1.24 & 4.01 & 1.26 & 4.75 & 1.18 \\
$F$ & \multicolumn{2}{c}{$35.65^{* * *}$} & \multicolumn{2}{c}{$115.85^{* *}$} & \multicolumn{2}{c}{0.34} \\
\hline Note. ${ }^{* *} p<.01 .{ }^{* * *} p<.001$ & \multicolumn{4}{c}{}
\end{tabular}

Table 3 Main effects of the choice to remain single

\begin{tabular}{lcccccc}
\hline & \multicolumn{8}{c}{ Factor } \\
\cline { 2 - 7 } Type of single & \multicolumn{2}{c}{ Warmth and sociability } & \multicolumn{2}{c}{ Loneliness and misery } & \multicolumn{2}{c}{ Success and potency } \\
\hline By choice & $M$ & $S D$ & $M$ & $S D$ & $M$ & $S D$ \\
Not by choice & 4.00 & 1.19 & 5.34 & 1.11 & 4.80 & 1.18 \\
$F$ & 4.41 & 1.12 & 5.05 & 1.05 & 4.53 & 1.10 \\
\hline Note. ${ }^{*} p<.05 .{ }^{* *} p<.01$ & \multicolumn{2}{c}{$9.84^{* *}$} & \multicolumn{2}{c}{$5.87^{*}$} & \multicolumn{2}{c}{$5.36^{*}$} \\
\hline
\end{tabular}


in the weighted dependent variable $(F(3,318)$ $=20.15, p<.001)$. Univariate analyses revealed that choosing to remain single had a significant effect on perceived warmth and sociability $(F(1,318)=9.84, p<.01)$. The perceived warmth and sociability of singles who chose to remain single $(M=4.00, S D=1.19)$ was lower than that of singles who did not choose to remain single $(M=4.41, S D=1.12)$. In addition, choosing to remain single had a significant effect on perceived loneliness and misery $(F(1,318)=5.87, p<.05)$. The perceived loneliness and misery of singles who chose to remain single $(M=5.34, S D=1.11)$ was higher than that of singles who did not choose to remain single $(M=5.05, S D=1.05)$. Finally, choosing to remain single had a significant effect on perceived success and potency $(F(1,318)=5.36, p<.05)$, but the effect was in the opposite direction from what we expected: the perceived success and potency level of singles who chose to remain single $(M=4.80, S D=1.18)$ was higher than that of singles who did not choose to remain single $(M=4.53, S D=1.1)$.

\section{Emotion as Mediating the Relationship Between the Choice to Remain Single and Stereotyping}

In order to examine whether the two emotions mediate the relationship between choosing to remain single and stereotypes of singles (Hypothesis 3), we conducted a series of hierarchic regression analyses according to Baron and Kenny's (1986) and Sobel's (1982) methods for examining mediation. These analyses revealed that anger fully mediated the relationships between choosing to remain single and stereotypes of loneliness and misery $(z=2.25, p<.05)$. Participants were angrier at singles by choice, and the angrier they were, they perceived the target as lonelier and more miserable. In addition, sympathy partially mediated the relationships between choosing to remain single

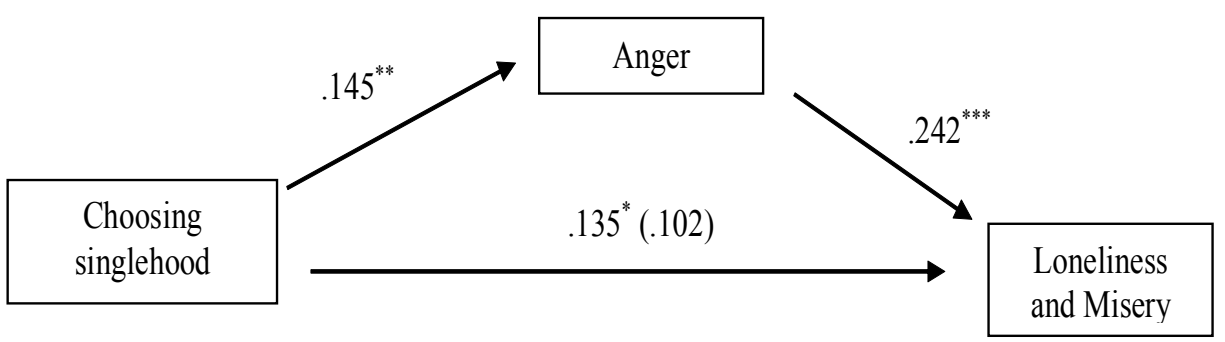

Note. ${ }^{*} p<.05^{* *} p<.01{ }^{* * *} p<.001$

Figure 1 Standardized regression coefficients for the relationship between the choice to remain single and stereotypes about loneliness and misery as mediated by anger. The standardized regression coefficient between choosing to remain single and stereotypes about loneliness and misery controlling for anger is in parentheses. 


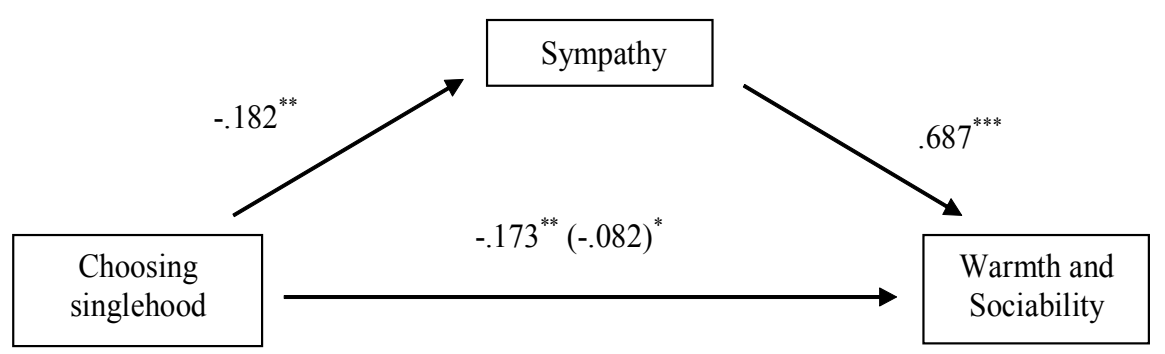

Note. ${ }^{*} p<.05{ }^{* *} p<.01{ }^{* * *} p<.001$

Figure 2 Standardized regression coefficients for the relationship between the choice to remain single and stereotypes about warmth and sociability as mediated by sympathy. The standardized regression coefficient between choosing to remain single and stereotypes about warmth and sociability controlling for sympathy is in parentheses.

and stereotypes of warmth and sociability $(z=-2.41, p<.01)$. Participants felt more sympathy towards singles by circumstance, and the more sympathy they felt, they perceived the target as warmer and more sociable. The findings of the mediation analysis for anger are presented in Figure 1, and the findings of the mediation analysis for sympathy are presented in Figure 2. No mediation effects were found for the success and potency dimension.

\section{Discussion}

In this study we examined stereotypes of and emotional reactions to single people. Our study yielded three main findings: First, single people were perceived as more lonely and miserable and as less warm and sociable than people who were in a romantic relationship. Second, we found that the two types of singles, singles who chose to remain single and singles who did not choose to remain single, are subject to different kinds of stereotypes. Singles who chose to remain single were perceived as more lonely and miserable and as less warm and sociable than singles who did not choose to remain single. However, singles who chose to remain single were also perceived as more successful and potent. Finally, anger fully mediated the relationship between choosing to remain single and the perception of singles as lonely and miserable, and sympathy partially mediated the relationship between choosing to remain single and the perception of singles as warm and sociable.

Findings from this study that single people are perceived more negatively than people who are in a romantic relationship, regardless of their age and gender, are in line with those of previous studies. Our findings, how- 
ever, broaden the geographic and cultural scope of the phenomenon.

Most previous studies (e.g., Hertel et al., 2007; Morris, et al., 2008) compared single and married individuals. Our results resemble Greitemeyer's (2009) findings that not being married is not necessarily the major reason for negative stereotypes of single people, and that not being in a romantic relationship (i.e., being "socially single") is enough to result in their being perceived negatively. Among the "socially single" group, all-time singles are perceived more negatively than singles who were partnered at some point in their life. In a study that compared perceptions of people not currently in a romantic relationship and never in a romantic relationship, those who have never been in a romantic relationship were perceived as less welladjusted and exciting and as more self-centered and envious than singles who had a past relationship (Morris, DePaulo, Hertel, \& Taylor, 2008).

Age and gender of the target person did not have any effect on the differences between stereotypes of singles versus people who are in a romantic relationship. It is possible that the family-oriented nature of Israeli society is so strong (Katz \& Lavee, 2005) that the pressure to be partnered is equal for males and females. It is also possible that the social pressure to get coupled starts at an earlier age in the Israeli society. Supporting this idea, the median age at first marriage for women is 26.6 in the US but only 25.0 in Israel, and for men 28.6 in the US compared to 28.0 in Israel (US Census Bureau, 2012; Israel Central Bureau of Statistics, 2012). In terms of the Developmental Life Tasks Model (Morris et al., 2008), the similar perceptions of 25 and 40-year-old singles suggest that in Israel, even at the age of 25 people are ex- pected to have already passed the milestone of getting involved in a serious romantic relationship. Those who fail to pass this life task are subject to negative stereotypes.

Even though singles were perceived as more lonely and miserable and as less warm and sociable than people who are in a romantic relationship, they were not perceived as less successful or potent. When analyzing each trait separately, we found that singles were perceived as more independent and career-oriented, and as less dependent than individuals who were in a romantic relationship. Previous research that used openended questions found positive perceptions of single people in terms of those same characteristics (Morris et al., 2008). Greitemeyer (2009) reported that single persons were viewed as more open to new experiences than coupled targets. Thus, it seems that singles, in addition to being subject to negative stereotypes, are also perceived positively in certain aspects.

Our second main finding suggests that singles who chose to remain single are perceived as more lonely and miserable than singles who look for a relationship. This finding is somewhat ironic: the former group has the status it wants, and the latter does not, yet the former group is perceived as more miserable. Future studies should explore the possiblity that perceivers do not really believe single people's statements about wanting to be single. It could be that people "punish" singles by choice by thinking they are lonely.

Our third finding is that singles who chose to remain single are perceived as less warm and sociable compared with singles who look for a partner. It could be that coupling and marriage are so powerful, that the only source of sociability that people recognize is the 
romantic partner. DePaulo and Morris (2006) argue that most people still hold what they call "Ideology of Marriage and Family". People yearn for a romantic relationship and find it the most important relationship an adult can have. Coupling and marriage are glorified - they are perceived as the source for happiness, life satisfaction and sense of fulfillment (Coontz, 2005). However, studies on the power of friendship have shown that not only romantic relationships but also relationships between friends can be beneficial for one's well-being. For example, the presence of a friend or merely thinking about a friend make challenges seem less challenging (Schnall, Harber, Stefanucci, \& Proffitt, 2008), and when a friend is nearby, anxious people feel more relaxed in social situations (Pontari, 2009). Support from friends, more than support from a spouse, is correlated with sense of mattering to others (Taylor \& Turner, 2001). The finding that singles by choice are perceived as less warm and sociable can be explained using ideas from the System Justification Theory and Attribution Theory. Singles who did not choose to remain single may be perceived as being in a transitory state that basically confirms the social norm of being in a romantic relationship. Thus, singles who did not choose to remain single will be grouped with romantically involved individuals. However, singles by choice deliberately ignore the status quo and therefore are more likely to be stereotyped.

In contrast to our hypothesis, our findings suggest that people who chose to remain single are perceived as more successful and potent than individuals who did not choose their singlehood. Some people may perceive the willingness to resist social norms as powerful. It is possible that people think that singles who chose to remain single have formulated an alternative value system, dedicating their time and energy to and succeeding in various domains outside of romantic relationships and family, and thus perceive them as more potent and successful than someone who is single not by choice. It may also be possible that singlehood by choice is perceived as "extreme singleness", and therefore, if singles are generally seen as more independent and career-oriented than coupled people, then for those who are single by choice, that difference will be even greater.

Our final main findings concern the mediating role of emotions: anger and sympathy mediated the relationship between the choice to remain single and stereotypes of singles. Singles who chose to remain single elicited anger, which led, in turn, to perceiving the single person as more lonely and miserable than singles who did not choose to remain single. Singles who did not choose to remain single elicited sympathy, which led, in turn, to perceiving the single person as more warm and sociable than the person who chose to remain single. Previous research has found causal relationships between attributions of control and failure and feelings of anger and sympathy (Bennett \& Flores, 1998; Parkins, 2006). Our study presents this link as the antecedent of stereotyping, thus suggesting that cognition (i.e., attributions of failure and control or lack of it) leads to emotions (i.e., anger or sympathy) and that these in turn activate stereotypes. Anger directed at people who violate social norms may decrease their sense of self-worth and in some cases even lead to violence. For example, female video game developers are the targets of harrassment and threats (Boston Globe, October 2014). Similarly, despite the rise of singlehood, society still struggles to 
accept people who choose to live without a partner. Singles who are happy with their relationship status often hear rude and obnoxious comments and have to face other people's misunderstanding of how one can actually have a satisfying and successful life without wanting a partner. This lack of empathy and acceptance can be perplexing for the single-by-choice.

\section{Limitations and Future Research}

Even though use of the Internet to conduct studies in behavioral sciences has become increasingly common in recent years and offers many advantages (Fraley, 2004), access to the Internet, although increasingly widespread, remains uneven. In addition, our study is subject to the usual limitations inherent in cross-sectional designs.

Future research might include several issues. First, the present study suggests that singles should not be seen as a homogeneous group. Future research should further explore how the diversity in this group is related to the different stereotypes of singles. In addition, a wider range of emotions may be tested to better understand how people emotionally react to singles. Lastly, examining other possible moderators of singlism, such as sexual orientation, conservative values and religiosity, may elucidate this phenomenon further.

Received June 23, 2014

\section{References}

Badahdah, A. M., \& Alkhder, O. H. (2006). Helping a friend with AIDS: A test of Weiner's attributional theory in Kuwait. Illness, Crisis \& Loss, 14(1), 43-54.

Barkas, J. L. (1980). Single in America. New York: Atheneum.
Baron, R. M., \& Kenny, D. A. (1986). The moderator-mediator variable distinction in social psychology research: Conceptual, strategic and statistical considerations. Journal of Personality and Social Psychology, 51, 1173-1182.

Bennett, T., \& Flores, M. (1998). Help giving in achievement contexts: A developmental and cultural analysis of the effects of children's attributions and affects on their willingness to help. Journal of Educational Psychology, 90, 659669.

Conley, T. D., \& Collins, B. E. (2002). Gender, relationship status, and stereotyping about sexual risk. Personality and Social Psychology Bulletin, 28, 1483-1494.

Coontz, S. (2005). Marriage, a history: From obedience to intimacy, or how love conquered marriage. New York: Viking.

Day, M. V., Kay, A. C., Holmes, J. G., \& Napier, J. L. (2011). System justification and the defense of committed relationship ideology. Journal of Personality and Social Psychology, 101(2), 291306.

DePaulo, B. M., \& Morris, W. L. (2005a). Should singles and the scholars who study them make their mark or stay in their place? Psychological Inquiry, 16, 142-149.

DePaulo, B. M., \& Morris, W. L. (2005b). Singles in society and in science. Psychological Inquiry, $16,57-83$.

DePaulo, B. M., \& Morris, W. L. (2006). The unrecognized stereotyping and discrimination against people who are single. Current Directions in Psychological Science, 15, 251-254.

Erchull, M. J., Liss, M., Axelson, S. J., Staebell, S. E., \& Askari, S. F. (2010). Well... She wants it more: Perceptions of social norms about desires for marriage and children and anticipated chore participation. Psychology of Women Quarterly, 34(2), 253-260.

Fraley, R. (2004). How to conduct behavioral research over the Internet. New York: Guilford.

Greitemeyer, T. (2009). Stereotypes of singles: Are singles what we think? European Journal of Social Psychology, 39, 368-383.

Hertel, J., Schütz, A., DePaulo, B. M., Morris, W. L., \& Stucke, T. S. (2007). She's single, so what? How are singles perceived compared with people who are married? Zeitschrift fur Familienforschung (Journal of Family Research), 19, 139-158.

Israel Central Bureau of Statistics. (2012). Statistical Abstracts of Israel. Jerusalem: Author. 
Jost, J. T., Banaji, M. R., \& Nosek, B. A. (2004). A decade of system justification theory: Accumulated evidence of conscious and unconscious bolstering of the status quo. Political Psychology, 25, 881-919.

Jost, J. T., \& Hunyady, O. (2002). The psychology of system justification and the palliative function of ideology. European Review of Social Psychology, 13, 111-153.

Jost, J. T., \& Hunyady, O. (2005). Antecedents and consequences of system-justifying ideologies. Current Directions in Psychological Science, 14(5), 260-265.

Katz, R., \& Lavee, Y. (2005). Families in Israel. In B. N. Adams \& J. Trust (Eds.), Handbook of world families (pp. 486-506). Thousand Oaks, CA: Sage.

Morris, W. L., DePaulo, B. M., Hertel, J., \& Taylor, L. C. (2008). Singlism - Another problem that has no name: Prejudice, stereotypes, and discrimination against singles. In M. A. Morrison \& T. G. Morrison (Eds.), The psychology of modern prejudice (pp. 165-194). New York: Nova Science.

Parkins, I. S. (2006). Adolescent perceptions of victims of school bullying. Unpublished doctoral dissertation. University of Cincinnati, Ohio.

Pontari, B. A. (2009). Appearing socially competent: The effects of a friend's presence on the socially anxious. Personality and Social Psychology Bulletin, 35, 283-294.

Sarkisian, N., \& Gerstel, N. (2008). Till marriage do us part: Adult children's relationships with their parents. Journal of Marriage and Family, 70(2), 360-376.

Schnall, S., Harber, K. D., Stefanucci, J. K., \& Proffitt, D. R. (2008). Social support and the perception of geographical slant. Journal of Experimental Social Psychology, 44, 1246-1255. Shostak, A. B. (1987). Singlehood. In M. B. Sussman \& S. K. Steinmetz (Eds.), Handbook of marriage and the family (pp. 355-368). New York: Plenum.

Sobel, M. E. (1982). Asymptotic confidence intervals for indirect effects in structural equation models. In S. Leinhardt (Ed.), Sociological methodology 1982 (pp. 290-312). Washington, DC: American Sociological Association.

Taylor, J., \& Turner, R. J. (2001). A longitudinal study of the role and significance of mattering to others for depressive symptoms. Journal of Health and Social Behavior, 42, 310-325.

Teitell, B. \& Borchers, C. (2014, October 30$)$. GamerGate anger at women all too real for gamemaker. The Boston Globe. Retrieved from http://www.bostonglobe.com/lifestyle/style/2014/ 10/29/threatening-video-gaming-industry-movement-grows-arlington-game-developer-forcedflee-her-home/BRHwDSGjMsSnHquH9jYQIJ/ story.html

U.S. Bureau of Labor Statistics (2014). Monthly Labor Review, September 2014.

U.S. Census Bureau. (2012). United States census 2012.

Weiner, B. (1986). An attributional theory of motivation and emotion. New York: SpringerVerlag.

Weiner, B. (1993). On sin versus sickness. A theory of perceived responsibility and social motivation. American Psychologist, 48(9), 957-965.

Weiner, B., Graham, S., Stern, P., \& Lawson, M. (1982). Using affective cues to infer causal thoughts. Developmental Psychology, 18, 278286. 


\title{
Z VLASTNEJ VÔLE ALEBO OKOLNOSŤAMI?: STEREOTYPY A POCITY O SLOBODNÝCH L'UĎOCH
}

\author{
G. S 1 o n i m, N. G u r - Y a i s h, R. K a t z
}

Súhrn: Štúdia sa venuje stereotypom a emočným reakciám týkajúcich sa l'udí, ktorí sú bud' slobodní z vlastnej vôle alebo vd’aka okolnostiam. Respondenti $(\mathrm{n}=480)$ si prečítali scenár opisujúci l’udí, ktorí boli slobodní či už z vlastnej vôle alebo nie a hodnotili svoje myšlienky a pocity vo vzt’ahu k týmto osobám. Ludia, ktorí sú slobodní z vlastnej vôle sú vnímaní ako osamelí a neštastní, menej prívetiví a spoločenskí než l’udia, ktorí sú slobodní ako výsledok okolností. Sú však vnímaní ako schopnejší a úspešnejší. Mediátormi vzt’ahu medzi vol'bou ostat' slobodný a úrovňou stereotypizácie sú hnev a súcit. Naše výsledky rozširujú spôsob, akým atribučná teória vysvetl'uje aktiváciu stereotypov. 